\title{
ANALIZA RAZLIKA EFEKATA 6-MJESEČNOG PROGRAMA STEP AEROBIKA KOD STUDENTICA KOJE VJEŽBAJU I STUDENTICA KOJE NEMAJU ORGANIZIRANO TJELESNO VJEŽBANJE.
}

\author{
Natalija Kurtović ${ }^{1}$, Nijaz Skender ${ }^{1}$, Naim Ćeleš ${ }^{1}$ i Adi Palić ${ }^{2}$ \\ ${ }^{1}$ Pedagoški fakultet Bihać, Bosna i Hercegovina \\ ${ }^{2}$ Nastavnički fakultet Univerziteta Džemal Bijedić u Mostaru, Bosna i Hercegovina
}

\section{Originalni naučni članak}

\section{SAŽETAK}

Na uzorku od 100 studentica Visoke zdravstvene škole Univerziteta u Bihaću je urađen eksperiment u trajanju od 6 mjeseci s ciljem utvrđivanja razlika između dvije grupe ispitanika i to jedne koja je radila step aerobik dva puta nedjeljno i druge kontrolne koja nije imala organizovano tjelesno vježbanje. Na osnovu t-testa $i$ diskriminacijske analize utvrđeno je da je došlo do statistički značajnih razlika između ove dvije grupe ispitanika. Rezultati pokazuju da je došlo do promjena kod ispitanika eksperimentalne grupe između inicijalnog i finalnog mjerenja a također se to odrazilo i na razlike između eksperimentalne i kontrolne grupe. Izolovana je jedna diskriminaciona funkcija koja ima vrlo visoku statističku značajnost.

Na osnovu dobijenih rezultata može se potvrditi da je došlo do poboljšanja rezultata morfoloških karakteristika kod studentkinja, iako su vježbale samo dva puta nedjeljno. Pokazalo se da je došlo i do redistribucije sastava tijela na račun poboljšanja volumena a na štetu masnog tkiva.

Ključne reči: step aerobik, morfološke karakteristike

\section{UVOD}

Aerobik predstavlja jedinstven fenomen u sportu a ubraja se među sportove nastale $u$ posljednjih 25 godina. Nastao je u Americi i počeo se širiti kasnih 70-tih godina a usmjerena je različitim uzrasnim dobima, (u početku, ženama) a kasnije i svima ostalim. Aerobnim vježbanjem se nastoje povećati sposobnosti koje se u modernom sportu definišu kao aerobni fitness (Sharkey, 1991) u smislu aerobne snage ili aerobnog kapaciteta što je indikator sposobnosti uzimanja, transporta i iskorištenja kiseonika. U aerobiku vrlo važnu ulogu ima savladavanje određenih motoričkih programa. Danas se zna da se pod upravljanjem pokretima, podrazumijeva stalna "komunikacija" između središnjeg živčanog sustava (SŽS) i perifernog sistema, za izvođenje pokreta, a zajedno s perifernim dotokom vrši korekciju pokreta pri čemu SŽS planira, programira i šalje ekstrmitetima naredbu (Mirkov, 2011). U aerobiku postoji beskonačan broj elementa pokreta i njihovih kombinacija (Zagorc, 1996). Većina dosadašnjih istraživanja koja se bave 
funkcionalnim, motoričkim i morfološkim karakteristikama studentkinja (Skender, Kendić, Tabaković i Dujisić, 2002), kao i uticajem pojedinih programa aerobika (Đug i Mikić, 2007), govore o pozitivnom uticaju transformacionih programa na uzorku ispitanika starosti 19 do 21 godine. Na osnovu prezentiranih rezultata na početku i na kraju provedenog fitness programa step aerobika u periodu od dva mjeseca sa frekvencijom 2 puta nedjeljno, te na osnovu značajnosti promjena testiranih T-testom, došli su do rezultata da je primjenjivani program step aerobika, kod grupe od 21 studenata kod primjenjivanih antropometrijskih varijabli proizveo značajne parcijalne promjene-efekte. U istraživanju (Oreb, Blarežina i Gošnik-Oreb, 1997) su došli do rezultata da nakon sprovođenja tromjesečnog programa plesnog aerobika u okviru nastave tjelesnog odgoja u trajanju po dva sata nedjeljno, utvrđena je izuzetna utilitarnost plesnog aerobika, posebno u poboljšanju ritmičnosti, frekvencije pokreta, eksplozivne snage i koordinacije. U jednom drugom istraživanju (Đug, Mikić i Mačković, 2008) gdje se utvrđivao nivo tranformacionih procesa morfoloških karakteristika kao posljedica šestomjesečnog programiranog fitness programa kod studentica prve i druge godine studija Univerziteta u Tuzli koji su pohađali izbornu nastavu iz predmeta Fitness. Starost ispitanika je 19-21 godine a istraživanjem je obuhvaćeno 199 studentica. Fitness program TBC-total body condition, koji je proveden sa drugom grupom ispitanika proizveo je značajne parcijalne efekte i to na smanjenju tjelesne mase i smanjenju potkožnog masnog tkiva što je jedan od osnovnih zadataka ovog fitness programa. Struktura tijela (tjelesna građa) procjenjuje se na taj način što električni signal prolazi lakše kroz dijelove tijela koji sadrže vodu (krv, urin, mišići) iz razloga što imaju bolju provodljivost, nego kroz kosti ili masno tkivo. Što je veća količina bezmasnog tkiva veća je provodljivost i manji je otpor. Kombinujući bioelektričnu imepedancu sa ostalim faktorima kao što su visina, težina, godine dobijaju se podaci o strukturi tjelesne mase (Nešić, Ostojić, Đokić i Šeper, 2012). Osnovni cilj ovog istraživanja je utvrđivanje efekata 6-mjesečnog programa Step aerobika u nekim antropološkim obilježjima kod studentica Univerziteta u Bihaću. Sekundarni cilj je analiza razlika efekata 6-mjesečnog programa Step aerobika nekih antropoloških obilježja kod studentica Univerziteta u Bihaću i studentica koji nisu imali organizovano tjelesno vežbanje.

\section{METODE}

Uzorak ispitanika činilo je 100 studentica Univerziteta u Bihaću podijeljenih $\mathrm{u}$ dvije grupe - eksperimentalnu i kontrolnu grupu. Eksperimentalnu grupu (E), koja je radila po modelu step aerobika, činilo je 50 studentica, a kontrolnu grupu $(\mathrm{K})$ koja nije bila podvrgnuta organizovanim programom vježbanja činilo je 50 studentica. Ispitanice Eksperimentalne grupe su radile 6 mjeseci po dva puta sedmično program Step aerobika koji je obilovao aerobnim vježbanjem u trajanju od najmanje 60 minuta. Struktura pokreta u Step aerobiku se odnosi na stalne promjene ritma i tempa kao i promjene potrošnje energije upotrebom stepera. Ispitanice koje su radile po programu STEP aerobika izvodile su pokrete koji su se sastojali od mnogobrojnih skokova, poskoka, koraka i okreta koreografijom uklopljenom u jednu cjelinu koja liči na moderni ples, ali i nakon svake koreografije radile su vježbe oblikovanja koje su izvodile 
za pojedinačne mišićne grupe. U istraživanju antropoloških obilježja uzorka obje grupe ispitanica primijenjene su dvije baterije testova za procjenu sljedećih antropoloških obilježja:

- AGE- Hronološka starost

- AVIS - Tjelesna visina se mjeri antropometrom po Martinu. Ispitanik je na čvrstoj vodoravnoj podlozi u uspravnom stavu. Glava ispitanika treba da bude u takvom položaju da je frankfurtska ravan horizontalna. Ispitanik ispravlja leđa koliko je moguće, a stopala sastavlja. Ispitivač stoji sa lijeve strane ispitanika i kontroliše da mu je atropometar postavljen neposredno duž zadnje strane tijela i vertikalno, a zatim spušta metalni prsten klizač da horizontalna ploča dođe na glavu ispitanika. Čita se rezultat na skali u visini gornje stranice trouglog proreza prstena - klizača. Rezultat se čita sa tačnošću od $0,1 \mathrm{~cm}$.

- AMAS- Masa tijela se mjeri vagom postavljenom na vodoravnu, čvrstu podlogu. Ispitanik bos stoji na sredini vage mirno, sve dok se cifre na vagi ne umire. Rezultat se očitava sa tačnošću od $0,1 \mathrm{~kg}$.

- BMI - Body mass index je odnos visine i težine

- BMR- Basal metabolic rate je osnovna metabolička stopa predstavlja ukupnu energiju koja se oslobađa iz tijela da bi se održala normalna funkcija tijela u fazi mirovanja kao što je disanje i cirkulacija. $(1 \mathrm{kcal}=4.184 \mathrm{~kJ})$

- OTPOR- Impedance očitava prisutni tjelesni otpor na električnu struju. Mišić se ponaša kao provodnik električne energije, a dipozno tkivo se ponaša kao otpornik.

- FAT \% - Procenat masti

- FAT MASS- Ukupna težina mase masnoće (u kg, lb) u tijelu

- FFM- Fat free mass se sastojala od mišića, kosti, tkiva, vode i ostale mase oslobođene masti u tijelu.

- TBW - Total body water je količina vode u tijelu

Za mjerenje tjelesnog sastava korišten je aparat body composition monitor model: Tanita BC-540. Ovaj aparat, u obliku portabl vage, pomoću instaliranog softvera mjeri bioelektričnu impedansu i tjelesnu težinu, a zatim, na osnovu izmjerenih podataka i unijetih parametara (pol, godine, tjelesna visina) izračunava procentualni udio masti u strukturi sastava tijela, mišićnu masu u kilogramima, procentualni udio vode u strukturi sastava tijela, tzv. fizički rejting (na skali od 1 do 9), bazalni metabolizama (BMR) u kilokalorijama i džulima, metaboličku starost i težinu kostiju. Za obradu podataka su uzete samo tri veličine (procenat masti, mišićna masa i procenat vode) kao najznačajnije za istraživanje. Uzorak varijabli za procjenu morfoloških karakteristika (Skender, 2008.) bio je:

- AOBGRU - Obim grudnog koša

- AOBNAD - Obim nadlaktice

- AOBTRB - Obim stomaka

- AOBNAT - Obim natkoljenice

- ANABTR - Kožni nabor stomaka

- ANABNAD - Kožni nabor nadlaktice

- ANABLE - Kožni nabor leđa.

Za mjerenje antropometrijskih karakteristika korišteni su antropometar po Martinu s preciznošću skale od $0,1 \mathrm{~cm}$, centimetarska traka dužine $1500 \mathrm{~mm}$ i kaliper.Mjerenja mofoloških karakteristika su mjerena po IBP (International Biological Program). Mjerenja obima su vršena centimetarskom vrpcom. Kožni nabori su mjereni kaliperom. Mjerenja su izvršena u jutarnjim satima u inicijalnom i finalnom mjerenju. Mjerenja je izvršio isti mjerilac da bi se moguće greške u načinu mjerenja smanjile na najmanju moguću mjeru. 
Rezultati mjerenja su obrađeni statističkim programom SPSS 17. Nakon što je provjerom normalnosti distribucije utvrđeno da podaci imaju normalnu distribuciju urađeni su T-test $\mathrm{i}$ diskriminativna analiza.

\section{REZULTATI}

Tabela 1. Deskriptivna statistika svih varijabli na inicijalnom mjerenju kod obje grupe ispitanika

\begin{tabular}{cccccc}
\hline grupe & Varijable & $\mathrm{N}$ & Mean & SD & KS test \\
\hline AVISTJ & 50 & 164,50 & 5,79 & 0,23 \\
AMASTJ & 50 & 59.64 & 10,29 & 0,58 \\
BMI & 50 & 21.78 & 3,83 & 0,19 \\
BMR & 50 & 6049.68 & 426,42 & 0,26 \\
OTPOR & 50 & 597.32 & 69,92 & 0,31 \\
FAT\% & 50 & 15.53 & 7,46 & 0,87 \\
FAT MASS & 50 & 44.09 & 3,25 & 0,40 \\
FFM & 50 & 32.28 & 2,37 & 0,36 \\
EBW & 50 & 84.97 & 6,48 & 0,39 \\
AOBGRU & 50 & 24.48 & 2,91 & 0,54 \\
AOBNAD & 50 & 74.37 & 8,34 & 0,28 \\
AOBTRB & 50 & 50.80 & 4,71 & 0,65 \\
AOBNAT & 50 & 1,76 & 0,61 & 0,91 \\
ANABTR & 50 & 1,58 & 0,48 & 0,32 \\
ANABNAD & 50 & 1,20 & 0,52 & 0,12 \\
ANABLE & 50 & 1,20 & 0,52 & 0,45 \\
\hline AVISTJ & 50 & 164,32 & 5,06 & 0,28 \\
AMASTJ & 50 & 61,17 & 10,05 & 0,65 \\
BMI & 50 & 21,84 & 5,47 & 0,91 \\
BMR & 50 & 6085,76 & 414,62 & 0,32 \\
OTPOR & 50 & 572,38 & 106,82 & 0,12 \\
FAT\% & 50 & 16,19 & 7,68 & 0,45 \\
FAT MASS & 50 & 44,38 & 3,57 & 0,87 \\
FFM & 50 & 32,48 & 2,60 & 0,40 \\
TBW & 50 & 84,73 & 6,42 & 0,36 \\
AOBGRU & 50 & 24,70 & 2,89 & 0,39 \\
AOBNAD & 50 & 75,32 & 7,58 & 0,65 \\
AOBTRB & 50 & 50,95 & 5,20 & 0,91 \\
AOBNAT & 50 & 1,85 & 0,55 & 0,32 \\
ANABTR & 50 & 1,57 & 0,47 & 0,12 \\
ANABNAD & 50 & 1,28 & 0,59 & 0,45 \\
ANABLE & 50 & 1,28 & 0,59 & 0,57 \\
\hline & & & &
\end{tabular}


Tabela 2. Deskriptivna statistika svih varijabli na finalnom mjerenju kod obje grupe ispitanika

\begin{tabular}{|c|c|c|c|c|c|}
\hline grupe & Varijable & $\mathrm{N}$ & Mean & SD & $\mathrm{KS}$ test \\
\hline \multirow{16}{*}{$\mathrm{E}$} & AVISTJ & 50 & 165,54 & 5,79 & 0,65 \\
\hline & AMASTJ & 50 & 59,81 & 10,88 & 0,91 \\
\hline & BMI & 50 & 20,60 & 4,21 & 0,32 \\
\hline & BMR & 50 & 5917,00 & 452,63 & 0,12 \\
\hline & OTPOR & 50 & 559,00 & 56,84 & 0,45 \\
\hline & FAT $\%$ & 50 & 22,95 & 7,85 & 0,57 \\
\hline & FAT MASS & 50 & 44,15 & 3,48 & 0,12 \\
\hline & FFM & 50 & 32,35 & 2,55 & 0,45 \\
\hline & TBW & 50 & 86,10 & 6,89 & 0,28 \\
\hline & AOBGRU & 50 & 25,20 & 3,26 & 0,65 \\
\hline & AOBNAD & 50 & 68,00 & 6,86 & 0,91 \\
\hline & AOBTRB & 50 & 52,45 & 5,13 & 0,32 \\
\hline & AOBNAT & 50 & 1,54 & 0,64 & 0,12 \\
\hline & ANABTR & 50 & 1,54 & 0,64 & 0,45 \\
\hline & ANABNAD & 50 & 1,28 & 0,47 & 0,87 \\
\hline & ANABLE & 50 & 1,27 & 0,59 & 0,28 \\
\hline \multirow{16}{*}{$\mathrm{K}$} & AVISTJ & 50 & 164,32 & 5,06 & 0,65 \\
\hline & AMASTJ & 50 & 61,79 & 9,90 & 0,91 \\
\hline & BMI & 50 & 22,97 & 3,80 & 0,32 \\
\hline & BMR & 50 & 6109,46 & 407,30 & 0,12 \\
\hline & OTPOR & 50 & 543,06 & 64,53 & 0,45 \\
\hline & FAT $\%$ & 50 & 25,32 & 6,69 & 0,12 \\
\hline & FAT MASS & 50 & 45,65 & 3,53 & 0,45 \\
\hline & FFM & 50 & 33,42 & 2,58 & 0,28 \\
\hline & TBW & 50 & 88,74 & 6,27 & 0,65 \\
\hline & AOBGRU & 50 & 26,48 & 3,34 & 0,91 \\
\hline & AOBNAD & 50 & 72,40 & 7,56 & 0,32 \\
\hline & AOBTRB & 50 & 54,26 & 5,23 & 0,12 \\
\hline & AOBNAT & 50 & 1,76 & 0,58 & 0,45 \\
\hline & ANABTR & 50 & 1,76 & 0,58 & 0,87 \\
\hline & ANABNAD & 50 & 1,28 & 0,47 & 0,28 \\
\hline & ANABLE & 50 & 1,27 & 0,59 & 0,65 \\
\hline
\end{tabular}

U okviru ove analize utvrđivane su statističke značajnosti razlika primijenjenih varijabli prije i nakon realizovanog STEP programa. U tabeli br. 3 su prikazane vrijednosti T-testa zavisnog uzorka za procjenu statističke značajnosti razlika u prostoru morfoloških karakteristika i sastava tijela. Radi bolje razumljivosti tabela, varijable su označavane tako što se u različitim vremenskim tačkama za inicijalno mjerenje na kraju dodavao sufiks I a za finalno mjerenje dodavao sufiks F.

Analizom tabele 3 uočene su statistički zanačajne promjene kod sljedećih varijabli morfoloških karakteristika: impedance, fat free mass, total body water, obima grudnog koša, nadlaktice, stomaka, natkoljenice i kožni nabor leđa. 
Tabela 3. .T-test u prostoru morfoloških karakteristika i sastava tijela eksperimentalne grupe E2 u inicijalnom i finalnom mjerenju

\begin{tabular}{lllllllll}
\hline & \multicolumn{9}{c}{$\begin{array}{l}\text { 95\% Confidence } \\
\text { VARIJABLE }\end{array}$} & Mean & \multicolumn{2}{c}{$\begin{array}{l}\text { Std. } \\
\text { Deviatior }\end{array}$} & Mean & \multicolumn{2}{c}{$\begin{array}{l}\text { Interval of the Diff. } \\
\text { Upper }\end{array}$} & Lower & & df & $\begin{array}{l}\text { Sig. } \\
\text { (tail) }\end{array}$ \\
\hline AMASI - AMASF &,- 64898 & 2,38049 &, 34007 & $-1,33274$ &, 03478 & $-1,908$ & 48 &, 062 \\
BMII - BMIF & $-1,12800$ & 4,42512 &, 62581 & $-2,38560$ &, 12960 & $-1,802$ & 49 &, 078 \\
BMRI - BMRF & $-23,70000$ & 99,94350 & 14,13415 & $-52,10363$ & 4,70363 & $-1,677$ & 49 &, 100 \\
OTPORI- OTPORF & 29,32000 & 91,21704 & 12,90004 & 3,39640 & 55,24360 & 2,273 & 49 &, 027 \\
FATPROI - FATPROF &, 67000 & 3,72626 &, 52697 &,- 38899 & 1,72899 & 1,271 & 49 &, 210 \\
FATMASI-FATMASF &,- 10200 & 2,65756 &, 37584 &,- 85727 &, 65327 &,- 271 & 49 &, 787 \\
FFMI-FFMF & $-1,26600$ & 1,17606 &, 16632 & $-1,60023$ &,- 93177 & $-7,612$ & 49 &, 000 \\
TBWI - TBWF &,- 93600 &, 85589 &, 12104 & $-1,17924$ &,- 69276 & $-7,733$ & 49 &, 000 \\
AOBGRUI - AOBGRUF & $-4,01000$ & 4,40682 &, 62322 & $-5,26241$ & $-2,75759$ & $-6,434$ & 49 &, 000 \\
AOBNADI - AOBNADF & $-1,77200$ & 1,40117 &, 19816 & $-2,17021$ & $-1,37379$ & $-8,942$ & 49 &, 000 \\
AOBTRBI-AOBTRBF & 2,91600 & 6,80952 &, 96301 &, 98076 & 4,85124 & 3,028 & 49 &, 004 \\
AOBNATI-AOBNATF & $-3,31000$ & 3,17749 &, 44936 & $-4,21303$ & $-2,40697$ & $-7,366$ & 49 &, 000 \\
ANABTRI-ANABTRF &, 08800 &, 46979 &, 06644 &,- 04551 &, 22151 & 1,325 & 49 &, 191 \\
ANABNADI - ANABNADF &,- 03360 &, 33154 &, 04689 &,- 12782 &, 06062 &,- 717 & 49 &, 477 \\
ANABLEI-ANABLEF &, 15040 &, 45446 &, 06427 &, 02124 &, 27956 & 2,340 & 49 &, 023 \\
\hline
\end{tabular}

Tabela 4. T-test u prostoru morfoloških karakteristika i sastava tijela eksperimnentalne i kontrolne grupe inicijalno mjerenje

\begin{tabular}{|c|c|c|c|c|c|c|c|c|}
\hline VARIJABLE & Mean & $\begin{array}{l}\text { Std. } \\
\text { Dev }\end{array}$ & $\begin{array}{l}\text { Std. Err } \\
\text { Mean }\end{array}$ & $\begin{array}{l}95 \% \mathrm{Co} \\
\text { Inte. of } \\
\text { uper }\end{array}$ & $\begin{array}{l}\text { nfid } \\
\text { he Dif. } \\
\text { lovwer }\end{array}$ & $\mathrm{t}$ & df & $\begin{array}{l}\text { Sig. } \\
\text { (2-tai) }\end{array}$ \\
\hline AMAS & $-2,0606$ & 8,09297 & 1,40881 & $-4,9302$ & ,80904 & $-1,463$ & 32 &, 153 \\
\hline BMI & $-1,12800$ & 4,42512 & ,62581 & $-2,38560$ & ,12960 & $-1,802$ & 49 &, 078 \\
\hline BMR & $-23,70000$ & 99,94350 & 14,13415 & $-52,1036$ & 4,70363 & $-1,677$ & 49 &, 100 \\
\hline OTPOR & 1,73939 & 9,14730 & 1,59234 & $-1,504$ & 4,9828 & 1,092 & 32 & ,283 \\
\hline FATPRO & 67000 & 3,72626 &, 52697 &,- 38899 & 1,72899 & 1,271 & 49 & ,210 \\
\hline FATMAS &,- 10200 & 2,65756 & ,37584 &,- 85727 & ,65327 &,- 271 & 49 & ,787 \\
\hline FFM & $-1,12800$ & 4,42512 & ,62581 & $-2,38560$ & , 12960 & $-1,802$ & 49 & ,078 \\
\hline TBW & $-23,70000$ & 99,94350 & 14,13415 & $-52,1036$ & 4,70363 & $-1,677$ & 49 &, 100 \\
\hline AOBGRU & 1,17879 & 4,23916 & ,73794 &,- 324 & 2,6819 & 1,597 & 32 & ,120 \\
\hline AOBNAD & 1,73939 & 9,14730 & 1,59234 & $-1,504$ & 4,9828 & 1,092 & 32 & ,283 \\
\hline AOBTRB & 1,17879 & 4,23916 & ,73794 &,- 324 & 2,6819 & 1,597 & 32 &, 120 \\
\hline AOBNAT & $-2,0606$ & 8,09297 & 1,40881 & $-4,9302$ & ,80904 & $-1,463$ & 32 & ,153 \\
\hline ANABTR & $-1,12800$ & 4,42512 & ,62581 & $-2,38560$ & , 12960 & $-1,802$ & 49 & ,078 \\
\hline
\end{tabular}




$\begin{array}{lllllllll}\text { ANABNAD } & , 21121 & , 89753 & , 15624 & -, 1070 & , 5294 & 1,352 & 32 & , 186 \\ \text { ANABLE } & -, 04152 & , 74377 & , 12947 & -, 3052 & , 2222 & -, 321 & 32 & , 751 \\ \text { AMAS } & -, 10200 & 2,65756 & , 37584 & -, 85727 & , 65327 & -, 271 & 49 & , 787\end{array}$

U tabeli br. 5 prikazane su razlike između Eksperimentalne i Kontrolne grupe u morfološkim karakteristikama i sastavu tijela u finalnom mjerenju. Utvrđene su vrijednosti razlika u sljedećim varijablama: masa tijela, body mass index, basal metabolic rate, otpor, procenat masti, ukupna težina mase masnoće (u kg, lb) u tijelu, fat free mass, total body water, kožni nabor leđa, obim natkoljenice i obim trbuha. Posebno je značajna razlika koja je ostvarena u morfološkoj dimenziji masa tijela gdje je utvrđena statistički značajna razlika na nivou $0.5 \%$. Ukoliko bi analizirali i varijable strukture tijela ukupna težina mase masnoće ( $\mathrm{u} \mathrm{kg}, \mathrm{lb}) \mathrm{u}$ tijelu i fat free mass, vidi se da su i one pokazale statistički značajne razlike ovih grupa ispitanika pogotovo sa aspekta što one kao ovakve učestvuju u masi tijela, kao i u potkožnom masnom tkivu.

Tabela 5.T-test u prostoru morfoloških karakteristika i sastava tijela eksperimnentalne i kontrolne grupe finalno mjerenje

\begin{tabular}{|c|c|c|c|c|c|c|c|c|}
\hline Varijable & Mean & $\begin{array}{l}\text { Std. } \\
\text { Dev }\end{array}$ & $\begin{array}{l}\text { Std. Err } \\
\text { Mean }\end{array}$ & $\begin{array}{l}95 \% \mathrm{Co} \\
\text { Inte. of }\end{array}$ & $\begin{array}{l}\text { nfid } \\
\text { the Dif. }\end{array}$ & $\mathrm{t}$ & $\mathrm{df}$ & $\begin{array}{l}\text { Sig. } \\
\text { (2-tai) }\end{array}$ \\
\hline AMASK - AMASE & $-2,0606$ & 8,09297 & 1,40881 & $\begin{array}{l}\text { uper } \\
-4,9302\end{array}$ & $\begin{array}{l}\text { lower } \\
\text {,80904 }\end{array}$ & $-1,463$ & 32 & ,153 \\
\hline BMIK - BMIE & 6,34242 & 12,38901 & 2,15665 & 1,9494 & 10,735 & 2,941 & 32 & ,006 \\
\hline BMRK - BMRE & 2,89697 & 4,26889 & ,74312 & 1,3832 & 4,4106 & 3,898 & 32 & ,000 \\
\hline OTPORK- OTPORE & 253,181 & 522,873 & 91,02064 & 67,778 & 438,58 & 2,782 & 32 & ,009 \\
\hline FATPROK - FATPROE & $-35,121$ & 91,64598 & 15,95352 & $-67,61$ & $-2,624$ & $-2,201$ & 32 & ,035 \\
\hline FATMASK-FATMASE & 4,80303 & 8,99908 & 1,56654 & 1,6121 & 7,9939 & 3,066 & 32 & ,004 \\
\hline FFMK-FFME & 4,60606 & 8,40992 & 1,46398 & 1,6240 & 7,5880 & 3,146 & 32 & ,004 \\
\hline TBWK - TBWE & 1,77576 & 4,62264 & 80470 & 1366 & 3,4148 & 2,207 & 32 & ,035 \\
\hline AOBGRUK - AOBGRUE & 1,30000 & 3,39273 & ,59060 & ,0969 & 2,5030 & 2,201 & 32 & 035 \\
\hline AOBNADK - AOBNADE & 1,73939 & 9,14730 & 1,59234 & $-1,504$ & 4,9828 & 1,092 & 32 & ,283 \\
\hline AOBTRBK-AOBTRBE & 1,17879 & 4,23916 & ,73794 &,- 324 & 2,6819 & 1,597 & 32 & ,120 \\
\hline AOBNATK-AOBNATE & 5,02727 & 10,84811 & 1,88841 & 1,180 & 8,8738 & 2,662 & 32 & ,012 \\
\hline ANABTRK-ANABTRE & 2,79091 & 6,54529 & 1,13939 & ,470 & 5,1117 & 2,449 & 32 & ,020 \\
\hline ANABNADK - ANABNADI & 21121 & 89753 & 15624 &,- 1070 & ,5294 & 1,352 & 32 & ,186 \\
\hline
\end{tabular}




$\begin{array}{lllllllll}\text { ANABLEK-ANABLEE } & -, 04152 & , 74377 & , 12947 & -, 3052 & , 2222 & -, 321 & 32 & , 751 \\ \text { AMASK - AMASE } & , 20939 & , 57657 & , 10037 & , 0049 & , 4138 & 2,086 & 32 & , 045\end{array}$

U ovoj podsekciji su analizirane kvantitativne promjene morfoloških karakteristika kod ekspreminetalne grupe E (grupa koja je radila STEP aerobik) nakon završenog programa $u$ trajanju od 6 mjeseci. Analizom tabele 6 vidi se da je u ovom prostoru došlo do kvantitativnih promjena. Došlo je do formiranja jedne značajne diskriminativne funkcije visine, .776 a koja ukazuje na vrlo visoku statističku značajnost od $0,01 \%$ što ukazuje na vrlo visok koeficijent značajnosti.

Tabela 6.Značajnost izoliranih diskriminativnih funkcija morfoloških karakteristika i sastava tijela eksperimetalne grupe $u$ inicijalnom i finalnom mjerenju

\begin{tabular}{|c|c|c|c|c|c|c|c|c|}
\hline Function & Eigenvalue & $\%$ of Variance & Cumulative \% & $\begin{array}{l}\text { Canonical } \\
\text { Correlation }\end{array}$ & Wilks' Lambda & Chi-square & df & $\mathrm{Si}$ \\
\hline 1 & $1,513(\mathrm{a})$ & 100,0 & 100,0 & 76 & 398 & 86,163 & 9 & 000 \\
\hline
\end{tabular}

Tabela 7. Struktura diskriminativne funkcije

\begin{tabular}{ll}
\hline & 1 \\
AOBNAT &, 255 \\
AOBGRU &, 253 \\
AOBNAD &, 227 \\
OTPORI(a) &,- 205 \\
AOBTRB &,- 155 \\
FFM(a) &, 145 \\
TBW &, 145 \\
ANABLE &,- 116 \\
AVIS(a) &,- 085 \\
FATPRO(a) &,- 059 \\
ANABNAD(a) &, 052 \\
ANABTR(a) &, 042 \\
FATMAS(a) &,- 034 \\
AMAS &, 031 \\
BMR(a) &, 027 \\
BMI(a) &, 005 \\
\hline
\end{tabular}


Tabela 8.Centroidi grupa

\begin{tabular}{ll}
\hline grupa & Function \\
& 1 \\
\cline { 1 - 1 } 1,00 & $-1,246$ \\
2,00 & 1,246 \\
\hline
\end{tabular}

U ovoj podsekciji su analizirane kvantitativne promene morfoloških karakteristika između ekspreminetalne grupe $\mathrm{E}$ i kontrolne grupe $\mathrm{K}$ nakon završenog programa, naglašavajući da je kod eksperimentalne grupe sproveden program step aerobika u trajanju od 6 mjeseci dok kontrolna grupa nije imala organizovano tjelesno vježbanje.

Analizirajući tabelu br. 9 u morfološkom prostoru došlo je do značajnih kvantitatitvnih promjena kod većine ispitanika, što je bilo i očekivano. Vidi se da je došlo do formiranja jedne značajne diskriminativne funkcije .633 a koja ukazuje u kojoj je korelaciji skup podataka na osnovu kojih sme vršila diskriminativna analiza sa diskriminativnom funkcijom. Statistička značajnost ove kanoničke koleracije je na nivou $0,01 \%$ što ukazuje na vrlo visoku vezu.

Tabela 9.Značajnost izolovanih diskriminativnih funkcija

\begin{tabular}{|l|l|l|l|l|l|l|l|l|}
\hline Function & Eigenvalue & \% of Variance & Cumulative \% & $\begin{array}{l}\text { Canonical } \\
\text { Correlation }\end{array}$ & Wilks' Lambda & Chi-square & df & Sig. \\
\hline 1 &, $754(\mathrm{a})$ & 100,0 & 100,0 &, 656 &, 570 & 41,578 & 14 &, 000 \\
\hline
\end{tabular}

Tabela 10.Struktura diskriminativne funkcije

\begin{tabular}{ll}
\hline & Function \\
& 1 \\
BMI &,- 441 \\
FATMAS(a) &,- 434 \\
FATPROC &,- 428 \\
AMASTJ &,- 422 \\
BMR &,- 404 \\
AOBTRB &,- 348 \\
FFM &,- 341 \\
\hline TBW(a) &,- 339
\end{tabular}




\begin{tabular}{ll} 
AOBNAT &,- 307 \\
OTPOR &, 281 \\
ANABLE &,- 269 \\
ANABTR &,- 215 \\
AOBNAD &,- 185 \\
AOBGRU &,- 172 \\
ANABNAT &, 118 \\
AVIS &, 073 \\
\hline
\end{tabular}

Tabela 11.Centroidi grupa

\begin{tabular}{ll}
\hline grupa & Function \\
& 1 \\
\cline { 1 - 1 } 1,00 &,- 697 \\
2,00 & 1,056 \\
\hline
\end{tabular}

\section{DISKUSIJA}

Sagledavajući rezultate istraživanja za eksperimentalnu grupu može se konstatovati da su ostvarene statistički značajne razlike pod uticajem STEP programa što je vidljivo iz tabela 3 i 5 . Ostvarene razlike su značajne u 8 varijabli morfoloških karakteristika i sastava tijela. Analizom tabele br.7 (struktura diskriminativne funkcije) najveći doprinos diskriminativnoj funkciji imaju testovi AOBNAT, AOBGRU i AOBNAD. U step programu pokreti koje su izvodile ispitanice u ovoj eksperimentalnoj grupi su se sastojali od mnogobrojnih skokova, poskoka, koraka i okreta koreografijom uklopljenom u jednu cjelinu koja liči na moderni ples, ali i nakon svake koreografije radile su vježbe oblikovanja koje su izvodile za pojedinačne mišićne grupe. Efekti step vježbanja su: jačanje mišića nogu i donjeg dijela leđa, zatezanje muskulature i povećanja vitalnosti cjelokupnog organizma. Analizirajući program vidi se da su ispitanice radile 2 puta nedjeljno u trajanju od jednog sata. Iz tih razloga je došlo do značajanih promjena na ovoj morfološkoj manifestaciji te su rezultati na ovoj diskriminativnoj funkciji pokazali da je program step statistički značajno uticao na poboljšanje dimenzija voluminoznosti tijela kroz manifestacije obim grudi, obim natkoljenice i obim nadlaktice. U tabeli br. 8 u kojoj su prikazani centroidi 
grupa vidi se da su napravili jasnu polarizaciju rezultata u inicijalnom i finalnom mjerenju kao i u prethodnoj grupi samo manjeg intenziteta.

Može se konstatovati da je program statistički značajno uticao na redistribuciju masti, voluminoznosti i obima skeleta, adipoziteta kod studentica eksperimentalne grupe. Razlog tome može se pronalaziti u programu koji su radile studentice eksperimentalne grupe. Naime program Step aerobika koji se izvodio 6 mjeseci po dva puta sedmično je obilovao aerobnim vježbanjem u trajanju od najmanje 60 minuta. Struktura pokreta u Step aerobiku se odnosi na stalne promjene ritma i tempa kao i promjene potrošnje energije upotrebom stepera. Ispitanice koje su radile po programu STEP aerobika izvodile su pokrete koji su se sastojali od mnogobrojnih skokova, poskoka, koraka i okreta koreografijom uklopljenom u jednu cjelinu koja liči na moderni ples, ali i nakon svake koreografije radile su vježbe oblikovanja koje su izvodile za pojedinačne mišićne grupe. Efekti step vježbanja su: jačanje mišića nogu i donjeg dijela leđa, zatezanje muskulature i povećanja vitalnosti cjelokupnog organizma.

U tabeli 5 je utvrđeno da je došlo do statistički zanačajnih razlika između dvije grupe ispitanika, (eksperimentalne i kontrolne). Na osnovu diskriminativne analize utvrđena je jedna diskriminativna funkcija koja ima vrlo visoku statističku značajnost.

Analizirajući tabelu 10 u kojoj je prikazana struktura diskriminativne funkcije vidi se da dosta veliki doprinos diskriminativnoj funkciji imaju varijable AMASTJ, AOBTRB, AOBNAT, ANABLE i ANABTR. To je iz razloga što su u Step aerobik programu pokreti koje su izvodile ispitanice u ovoj eksperimentalnoj grupi između ostalog značajno opteretile mišiće donjih ekstremiteta a rezultati su se odrazili i na nabor leđa i nabor trbuha. Pokreti koji se izvode u step aerobiku značajno opterećuju i mišiće trbuha jer kod različitih pokreta penjanja u vertikalnoj ili horizontalnoj ravni mišići trbuha igraju veoma važnu ulogu i konstantno su aktivni. Naravno da se program odrazio i na smanjenje mase kod eksperimentalne grupe što je direktna posljedica programa Step aerobika. Ovim se potvrđuje da je Step aerobik program kao aerobno vježbanje statistički značajno uticao na smanjenje mase i potkožnog masnog tkiva kao i obima trbuha kod ispitanica eksperimentalne grupe što je i cilj aerobika kao takve. Ovu konstataciju potvrđuju i centroidi grupa koji pokazuju i razliku u polu i velikoj udaljenosti između grupa. Kontrolna grupa nije imala nikakav organizovani program ali nije se moglo uticati i izvršiti potpunu kontrolu 
provođenja njihovog slobodnog vremena. Ipak su rezultati diskriminativne analize pokazali da su ove 4 varijable napravile najveću diskriminaciju između ove dvije grupe ispitanika.

$\mathrm{Na}$ osnovu dobijenih rezultata u ovom istraživanju može se potvrditi da je step aerobik vrlo značajno uticao na poboljšanje morfoloških karakteristika kod studentica Univerziteta u Bihaću. Iako su vježbale samo dva puta nedjeljno pokazalo se da je značajan uticaj ostvaren u većini varijabli morfološkog prostora i da je izvršena redistribucija sastava tijela na račun poboljšanja volumena a na štetu masnog tkiva. Vjerovatno bi rezultati u motoričkim sposobnostima pokazali značajno bolje rezultate no, na žalost, to ovde nije istraživano.

\section{ZAKLJUČAK}

Rezultati do kojih se došlo u istraživanju primijenjenom na uzorku od 100 ispitanika studentske populacije Univerziteta u Bihaću govore u prilog tome da je step aerobik vrlo podesan oblik aktivnosti i sporta primjeren ovom uzrastu. T-testom je utvrđena razlika između aritmetičkih sredina eksperimentalne i kontrolne grupe u gotovo svim karakteristikama morfoloških osobina i sastava tijela. Rezultati diskriminativne analize ukazuju na to da je izlovana jedna diskriminativna funkcija vrlo visoke značajnosti. Također analizirajući rezlike između inicijalnog i finalnog mjerenja kod eksperimentalne grupe vidljivo je da je program prouzrokovao značajne statističke promjene u domenu većine morfoloških karakteristika i nekih varijabli strukture tijela. To govori u prilog konstataciji da je došlo do redistribucije u sastavu tijela u korist stvaranja muskulature u odnosu na količinu masti što je prouzrokovao program koji je obilovao aerobnim vježbanjem, raznim vrstama skokova, preskoka i step koraka. U ovom istraživanju je potrvđeno da je step aerobik vrlo značajan sport koji treba upražnjavati u studentskom uzrastu. Naime, studentice su opterećene predavanjima, nastavom, učenjem, pa se to sasvim sigurno negativno odrazi na njihove morfološke karakteristike, a samim tim i na strukturu sastava tijela kao i na druga antropološka obilježja. 


\section{LITERATURA}

Đug, M. \& Mikić, B., (2007): Uticaj step aerobika na transformaciju antropometrijskih karakteristika i motoričkih sposobnosti studenata. Sport u 21 vijeku, Sport Mont, 129-133.

Đug, M., Mikić, B. \& Mačković, S. (2008): Efekti transformacionih procesa antropoloških karakteristika studentica pod uticajem modelovanog programa aerobika. Zbornik apstrakata ,Ekologija, zdravlje, rad, sport“, (pp. 124-130). Banja Luka, BIH: Univerzitet u Banjoj Luci.

Mirkov, D. M. (2011): Motorička kontrola: Znanstveno područje, kratak pregled pojmova i metoda. In I. Jukić, C. Gregov, S. Šalaj, L. Milanović, T. Troš-Bobić i D. Bok (Ed.), Zbornik radova 9. Medjunarodna konferencija ,Kondicijska priprema sportaša 2011“, (pp. 21-27), Zagreb, RH: Kineziološki fakultet Sveučilišta u Zagrebu, Udruga kondicionih trenera Hrvatske.

Nešić, N., Ostojić., S., Đokić, Z. \& Šeper, V. (2012): Razlike u regionalnoj mišićnoj distribuciji kod fudbalera. Tims Acta, 6(2), 43-56.

Oreb, G., Blarežina, Đ. \& Gošnik-Oreb, J. (1997): Utjecaj plesne aerobike na motoričke sposobnosti studentica. In D. Milanović (Ed.), 1. Međunarodna konferencija „,Kineziologija - Sadašnjost i budućnost“ (pp 56-59), Zagreb, RH: Fakultetu za fizičku kulturu Sveučilišta u Zagrebu.

Skender, N., S. Kendić., M. Tabaković. \& N. Dujisić. (2002): Utjecaj nekih antropometrijskih parametara na motoričke sposobnsoti studentica Pedagoškog fakulteta Univerziteta $\mathrm{u}$ Bihaću. Homosportikus, (1/2), 113 - 117.

Skender, N. (2008). Transformacioni procesi antropolokih obilježja pod utjecajem posebnog kineziološkog programa. Bihać, BIH: Pedagoškli fakultet Bihać.

Sharkey, B.J. (1991): New dimensions in aerobic fitness. Champaing: Human Kinetics Books.

Zagorc, M. (1996): Klasifikacija nekih struktura pokreta u aerobici. Kineziologija, 28(1), 29 - 35.

Primljeno: 23.06.2017.

Odobreno: 26.06.2017.

Korespodencija:

Mr Natalija Kurtović

J.U. Pedagoški fakultet u Bihaću

Luke Marjanovića b.b.

77000 Bihać

tel: $037 / 229-850$

fax: 037/229-878

natalijakurtovic@yahoo.com 